\title{
Assessment of the level of Realization of Sustainable Development Goals: Evidence from Manufacturing Firms in Nigeria
}

\author{
Nnachi Egwu Onuoha \\ Department of Accountancy/ Banking and Finance \\ Alex-Ekwueme Federal University, Ndufu-Alike, Ebonyi State, Nigeria \\ Gregory Onuora Okoye \\ Department of Accountancy \\ Madonna University, Okija, Anambra State, Nigeria
}

\begin{abstract}
Studies on the extent of realization of the sustainable development goals from the perspective of manufacturing firms in Nigeria are sparse. Accordingly, this study investigates: the extent sustainable development goals have been realized by manufacturing firms in Nigeria; the extent the social strand of sustainable development goals has been realized by the firms; the extent the environmental strand of sustainable development goals has been realized by the firms and the difference between the extent of realization of the social and environmental strands of the sustainable development goals by these firms. To achieve the above objectives, primary data set was collected from the 2017 annual reports of ten manufacturing firms in Nigeria using content analysis. The collected data were analyzed using $\mathrm{t}$ test and wilcoxon signed rank test for related samples. The results of the analysis indicate that: the extent of realization of sustainable development goals by manufacturing firms in Nigeria is insignificant, the extent of realization of the social strand of sustainable development goals by the firms is significant and the extent of realization of the environmental strand of sustainable development goals by the firms is insignificant. The result further shows a significant difference between the extent of realization of the social and environmental strands of the sustainable development goals by the firms. The results of this study offer insight that would enable policy makers to insist on tighter environmental measures for manufacturing firms in Nigeria.
\end{abstract}

Key words: Sustainability, Sustainable development, Sustainable Development Goals.

\section{INTRODUCTION}

The need to ensure sustainability in virtually every aspect of social, economic and environmental issues has continued to top the agenda in not only business world but in every political consideration. Consequently, each contemporary corporate economic, social and environmental decision cannot be said to be complete without the sustainability contemplation. As a result, sustainability-related issues get growing attention amongst companies [Boeva, Zhivkova \& Stoychev, 2017]. Similarly, governmental political decisions are very often expected to be influenced by sustainable development considerations. As noted by Galbreath, Singh \& Van der Zahn [2008, p. 6]. "Sustainability is current one of the more hotly contested issues in the media, and at governmental and business levels" 
Following the release of the Bruntland Commissions report in 1987 on sustainable development, companies started to entrench the concept of sustainable development in the way they strategize, operate, and communicate inside their various markets [Groenewald, \& Powell, 2016]. According to the coauthors, financial crisis of 2008 has shifted focus of how firms operate to not only on profit but on environment related problems. Companies also are faced with criticism on increasing scale for creating both social and environmental problems as well [Dimitrov \& Davey, 2011, as cited in Groenewald, \& Powell, 2016]. The economic, social and environmental issues raised above, as the generally considered three strands of sustainable development, have been referred to as the three triple-bottom line considered as the three 'P's' which represent profit, people and planet [Groenewald, \& Powell, 2016]. In other to survive in the long-run companies, according to Brundtland [1987, as cited in Groenewald \& Powell, 2016], can no longer afford to focus on economic gains and ignore the impact of its pursuit of this gain on society and environment.

However, considering the increasing importance accorded to this concept of sustainable development, and the exceptional attention paid to it, in 2015, UN general assembly offered the world seventeen sustainable development goals (SDGs). But the extent of accomplishment of these rather ambitious goals appears to be either unexplored or underexplored and underrepresented in the extant literature. Accordingly, this paper, in the main, investigates: the extent of realization of the sustainable development goals by manufacturing firms in Nigeria; the extent of realization of the social aspect of the sustainable development goals by the manufacturing firms in Nigeria; the extent of realization of the environmental aspect of the sustainable development goals by the manufacturing firms in Nigeria and the difference between the extent of realization of the social and environmental aspects of the sustainable development goals by the manufacturing firms in Nigeria.

The results of our study shows that: the extent of realization of sustainable development goals by manufacturing firms in Nigeria is insignificant; the extent of realization of the social strand of sustainable development goals by the firms is significant and the extent of realization of the environmental strand of sustainable development goals by the firms is insignificant. The result further shows a significant difference between the extent of realization of the social and environmental strands of the sustainable development goals by the firms.

Our study contributes empirically by exploring the extent of realization of the sustainable development goals by manufacturing firms in Nigeria. By so doing, the study extends and deepens extant empirical literature on sustainable development goals.

Following is the organization of the remainder of this paper. Whereas Section two displays review of related literature and hypothesis development, section three details issues on methodology. Then, sections four and five address the issues of results and conclusion and implication, respectively. 


\section{REVIEW OF RELATED LITERATURE AND HYPOTHESES DEVELOPMENT Sustainability and Sustainable Development goals}

As a result of the increasing importance attaching to the concept of sustainability, there appears to be a growing consciousness about it among firms and governments across the globe. According to Abdul Manab, Abdul Aziz, and Othman [2017], "Sustainability is increasingly prevalent in firms globally as the stakeholders are demanding that businesses become more transparent in environmental, social and governance (ESG) practices" [p. 1561]. Globally, the concept of sustainability is, at the present, an important topic and a key cause of worry throughout the world [Aggarwal, 2013]. "Indeed, corporate sustainability refers to companies that, while implementing their growth and development strategies, meet the needs of their key stakeholders in a balanced way that, through sustainable development, will allow future generations to fulfill their potential" [Riboldazzi, 2016, p. 7].

However, the multifaceted nature of sustainability has led firms to owe three responsibilities to the society which result to difficult corporate decisions with key environmental, economic and social consequences [Galbreath et. al., 2008]. According to Pintea and Fulop [2014], sustainability necessitates fresh standards of performance that goes beyond just the economic aspect for the national and transnational companies and these standards should be incorporated into strategy development of these companies to make sure that activities carried out are sustainable by harmonizing the environmental, economic and social goals.

Although Sustainability can as well be viewed as the strategy of the process of sustainable development but when a need arises to attain great living standard of people and economic advancement without destroying the planet, the concept of sustainable development comes in [ Boeva et al., 2017]. Nonetheless, information regarding the extent an organization has worked towards ensuring that the planet or the environment is not ruined should be made available to the stakeholders of this organization. Very often organizations provide this information with varied intentions. Specifically, while stakeholder theory states that environmental protection information is disclosed because it is demanded by the stakeholders [Yu \&Freedman, 2011, as cited in Boeva et al., 2017], legitimacy theory is of the view that firms tend to behave in accord with how the society needs them to behave (Boeva et al., 2017). However, this information, Boeva et al. [2017] argue, is not certainly factual. But whether or not any environmental or social information disclosed in the annual reports of companies is factual, it is patent that management engages in voluntary disclose of information to either satisfy the environmental or social information need of stakeholders or that of the society.

Drawing on the foregoing discussion, it is clear that information regarding the economic, environmental and social strands of sustainable development is expected to be disclosed in the annual reports of firms. So, the attempts made by manufacturing firms to attain the seventeen sustainable development goals [SDGs] set in 2015 during the United Nations [UN] General Assembly ought to be disclosed in their annual reports. Because of the wide ranging and ambitious nature of the SDGs, the UN beckons on all national governments to develop strategies to attain them, and recognized the role companies, whether national or transnational, should play in realizing these goals [Jones, Hillier \& Comfort, 2017]. According 
to Jones et al. [2017], "companies that work to adopt the SDGs will improve trust amongst their stakeholders, reduce regulatory and legal risks and build resilience to future costs and regulatory and legislative requirements"[p. 40]. Further, whereas Legitimacy theory states that corporate sustainability lessens boycotts and risk of regulatory actions by stakeholders and makes stronger firms license to run their business, stakeholder theory asserts that corporate sustainability assists in making the relationship that subsists between a firm and stakeholders stronger[Aggarwal, 2013]. So, it is expected that manufacturing firms in Nigeria should play significant roles in helping the Nigerian government to work to attain these rather ambitious SDGs in view of the benefits that derive from doing so.

\section{Sustainable Development and Sustainable Development Goals}

Extant literature indicates increasing empirical studies on sustainable development and corporate governance nexus, sustainable development and corporate performance [Galbreath et al., 2008; Aggarwal, 2013; Pintea \& Fulop, 2014; Janggu, Darus, Zain, and

Sawani, 2014; Stojanović, Ateljević' \& Stević, 2016; Groenewald, \& Powell, 2016; Boeva et al., 2017; Abdul Manab et al., 2017; Okaro, Ofoegbu \& Okafor, 2018; Sar, 2018] and studies that are aimed at exploring extant literature to determine varied meanings attaching to sustainable development [See, Jordan, 2008]. For example, Sar [2018] explored the effect of corporate governance on sustainability and found positive association between corporate governance and economic performance, environment performance, and social equity performance (the three aspects of sustainability performance). Galbreath et al. [2008] investigated the relationship among sustainability and corporate governance using evidence from oil and gas companies in Australia and Canada. They found board size to significantly predict environmental quality and of social responsiveness of firms in Australia and none of the variables of corporate governance offer explanations for variations in the sustainability variables with respect to oil and gas firms in Canada. Okaro, et al. [2018] explored sustainable development and corporate governance nexus using evidence from Nigeria and found a positive link between the principles of corporate governance and sustainable development.

Further, Stojanović et al. [2016] investigated the relation that subsists between good governance and sustainable development and found a significant positive relation, while Abdul Manab et al., [2017], studied The impact of compliance with corporate governance principles and sustainability risk management success factors on the survival of firm and found Corporate governance compliance as one of the main reasons for sustainability risk management adoption. They also found that corporate governance compliance, leadership and risk culture have impact on firms' survival. Aggarwal [2013] explored the effect of Sustainability on financial performance of firms and found no significant relationship between the whole sustainability rating and financial performance.

Furthermore, considering the relation that subsists between corporate governance and disclosure of sustainability information, Janggu et al. [2014] investigated the effect of good corporate governance (CG) on disclosure of sustainability information of firms in Malaysia and found board independence and board ownership corporate governance variables as not significant in explaining variations in sustainability disclosure. But, in view of the need to 
ascertain whether engagement in sustainable development activities are related to corporation financial performance, Groenewald and Powell 2016] explored the relationship between sustainable development initiatives and improved corporation financial performance using evidence from South African and showed that a positive relations subsists between sustainability performance and financial performance.

From the reviewed extant empirical studies, it would be observed that the extent of realization of the sustainability development goals is either unexplored or underexplored. Thus, little or nothing is known regarding the extent of realization of the sustainable development goals, especially from the perspective of manufacturing firms in Nigeria. Accordingly, we state the hypotheses that follow.

H1: the extent of realization of the sustainable development goals by manufacturing firms in Nigeria is not significant.

H2: the extent of realization of the social strand of the sustainable development goals by the manufacturing firms in Nigeria is not significant.

H3: the extent of realization of the environmental strand of the sustainable development goals by the manufacturing firms in Nigeria is not significant.

H4: the difference between the extent of realization of the social and environmental strands of the sustainable development goals by the manufacturing firms in Nigeria is not significant.

\section{METHODOLOGY}

Ex-post facto research design is selected for this study. This is because of its use in the study of events that have taken place already. Thus, data exist already and attempts are not made to either manipulate or control the explanatory variables [Onwumere, 2009], and the study involved collection of data set, which already exist, from the 2017 annual reports of 10 manufacturing firms in Nigeria. The choice of the 10 manufacturing firms selected was based on availability of their 2017 annual reports in their official websites.

To collect the data set for testing hypotheses 1, 2, 3 and 4, content analysis of 10 annual reports of the studied firms was conducted. The choice of content analysis is consistent with prior disclosure studies [see Nawaiseh, 2015; Gatimbu \& Wabwire, 2016]. Any disclosed indicator (item) of sustainable development goals in the annual reports was scored 1 or 0 if not disclosed. Following Chaklader and Gulati [2015], disclosure scores were computed by applying the formula that follows.

Disclosure Scores (DSs) = Total number of items that appear in the annual reports of the firms / Maximum number of items that should appear in the annual reports $\times 100 \%$

These DSs were deployed to assess both the extent of realization of the sustainable development goals by the studied manufacturing firms and the extent of realization of their social and environmental strands. 
However, to conduct the content analysis, a seventeen items disclosure index (see appendix A) was designed based on the 2015 UN seventeen sustainable development goals. The data collected were subjected to normality test. The result of this test is depicted in table 1 . From this table, based on Shapiro-Wilk test, it would be observed that whereas both extent of realization of sustainable development goals and extent of realization of social strand variables are approximately normally distributed, extent of realization of environmental strand variable is not normally distributed. Consequently, parametric and nonparametric tests were conducted deploying both t-test and one sample Wilcoxon signed rank test and its two related samples variety, respectively.

Table 1: Test of Normality

\begin{tabular}{|c|c|c|c|c|c|c|}
\multicolumn{1}{c|}{} & \multicolumn{1}{c|}{ Table 1: Test of Normality } \\
\cline { 2 - 7 } & \multicolumn{3}{c|}{ Kolmogorov-Smirnov } & \multicolumn{3}{c|}{ Shapiro-Wilk } \\
\cline { 2 - 7 } & Statistic & Df & Sig. & Statistic & Df & Sig. \\
\hline $\begin{array}{c}\text { Extent of realization of } \\
\text { Sustainable Development Goals }\end{array}$ & 0.2 & 10 & 0.200 & 0.876 & 10 & 0.118 \\
\hline $\begin{array}{c}\text { Extent of realization of } \\
\text { Environmental goals }\end{array}$ & 0.29 & 10 & 0.017 & 0.76 & 10 & 0.005 \\
\hline $\begin{array}{c}\text { Extent of realization of Social } \\
\text { goals }\end{array}$ & 0.297 & 10 & 0.013 & 0.868 & 10 & 0.095 \\
\hline
\end{tabular}

Source: Authors Compilation from SPSS (Version 22) output

\section{RESULTS}

In this section, results are presented based on descriptive and inferential statistics.

\section{Descriptive Statistics}

Table 2 presents the descriptive statistics for the extent of realization of SDGs, social and environmental goals variables. From this table, it will be seen that the mean extent of realization of the sustainable development goals is $51.2 \%$, an indication of above average performance. This suggests that the performance of the ten studied manufacturing firms with respect to their efforts to key into sustainable development goals is above average. However, the table indicates that this performance level of the manufacturing firms is traceable to their social strand which has a mean of $65 \%$, which is above average, and environmental strand with a mean of $29.99 \%$. While the $65 \%$ indicates above average performance, $29.99 \%$ performance shows below average performance.

Very clearly, 29.99\% of the mean of the extent of realization of environmental goals suggests that the studied firms are not doing well with respect to the level of effort they have so far put in to achieve the environmental strand of sustainable development goals. 
Onuoha N. E., Okoye G. O. (2020). Assessment of the Level of Realization of Sustainable Development Goals: Evidance from Manufacturing Frims in Nigeria. Advances in Social Sciences Research Journal, 7(3) 330-340.

Table 2: Descriptive Statistics

\begin{tabular}{|c|c|c|c|c|}
\cline { 2 - 4 } \multicolumn{1}{c|}{} & Minimum & Maximum & Mean & $\begin{array}{c}\text { Standard } \\
\text { Deviation }\end{array}$ \\
\hline $\begin{array}{c}\text { Extent of realization of } \\
\text { Sustainable Development Goals }\end{array}$ & 29.4 & 82.4 & 51.19 & 19.0289 \\
\hline $\begin{array}{c}\text { Extent of realization of Social } \\
\text { goals }\end{array}$ & 0 & 85.7 & 65 & 37.1488 \\
\hline $\begin{array}{c}\text { Extent of realization of } \\
\text { environmental goals }\end{array}$ & 50 & 80 & 29.99 & 9.71825 \\
\hline
\end{tabular}

Source: Authors Compilation from SPSS (Version 22) output

\section{Inferential Statistics}

Table 3 presents the results of the one sample t test conducted. The table shows that the level of realization of sustainable development goals is not significant at $5 \%$ level. This is because $\mathrm{t}$-score is 0.198 and $\mathrm{p}$-value of the t-score is 0.848 , which is higher than $5 \%(0.05)$ level of significance. This finding clearly supports hypothesis one (H1) which states that the extent of realization of the sustainable development goals by manufacturing firms in Nigeria is not significant.

Further, table 3 indicates that the level of achievement of the social component of the sustainable development goals is significant at $5 \%$ level of significance. This is because the p-value of the t-score of 4.881 is 0.001 , which is lower than $5 \%(0.05)$ level of significance. This finding clearly does not support hypothesis two (H2) which states that the extent of realization of the environmental aspect of the sustainable development goals by the manufacturing firms in Nigeria is not significant.

Table 3: T-test Result

\begin{tabular}{|c|c|c|c|}
\cline { 2 - 4 } \multicolumn{1}{c|}{} & T & df & Sig. (2-tailed) \\
\hline $\begin{array}{c}\text { Sustainable Development } \\
\text { Goals }\end{array}$ & 0.198 & 9 & 0.848 \\
\hline Social Goals (SG) & 4.881 & 9 & 0.001 \\
\hline
\end{tabular}

Source: Authors Compilation from SPSS (Version 22) output.

Table 4 presents the results of the one sample Wilcoxon signed rank test conducted. The table also shows the results of the Wilcoxon signed rank test for two related samples conducted. From this table, it will be observed that the level of environmental performance or achievement of the environmental component of the sustainable development goals is insignificant at $5 \%$ level of significance. This is because the p-value of the test score of -1.71 is 0.087 , which is higher than $5 \%(0.05)$ level of significance. This finding also supports hypothesis three (H3) which states that the extent of realization of the environmental strand of the sustainable development goals by the manufacturing firms in Nigeria is not significant.

Further, table 4 indicates that the difference between the level of attainment of the social and environmental component of the sustainable development goals is significant at 5\% level of significance. This is because p-value of the test score of 2.299 is 0.021 , which is lower than 
$5 \%(0.05)$ level of significance. This finding clearly does not support hypothesis four (H4) which states that the difference between the extent of realization of the social and environmental strands of the sustainable development goals by the manufacturing firms in Nigeria is not significant.'

Table 4: Wilcoxon Signed Rank Sheets

\begin{tabular}{|c|c|c|}
\cline { 2 - 3 } \multicolumn{1}{c|}{} & Test Value & Sig. (2-tailed) \\
\hline Environmental Goals (EG) & -1.71 & 0.087 \\
\hline Difference between SG and EG & 2.299 & 0.021 \\
\hline
\end{tabular}

Source: Authors Compilation from SPSS (Version 22) output.

Whereas the above descriptive analysis shows that the mean of the extent of realization of the sustainable development goals is above average, the inferential analysis indicates that the level of realization of sustainable development goals is not significant at $5 \%$. This implies poor performance of the ten studied manufacturing firms with respect to their efforts to key into sustainable development goals.

Descriptive analysis also shows below average of the extent of realization of the environmental strand of the sustainable development goals by the manufacturing firms in Nigeria while the inferential analysis indicates insignificant level of achievement of the environmental component of the sustainable development goals. This suggests that the studied firms are not doing well with respect to the level of effort they have so far put in to achieve the environmental strand of sustainable development goals.

The finding further indicates that the level of attainment of the social component of the sustainable development goals is significant. This is consistent with the above average of the level of realization of the social strand of the sustainable development goals by the manufacturing firms in Nigeria. This finding suggests that the studied firms are doing well with respect to the level of effort they have put in to achieve the social strand of sustainable development goals. This is also a clear indication that manufacturing firms in Nigeria, although concentrating more on the social strands of these SDGs, are playing the roles which, according to Jones et al. [2017], UN recognized that companies, whether national or transnational, should play in realizing SDGs. The quite impressive performance in realizing the social goals may also be to take advantage of the benefits that flow from corporate sustainability. This is because, according to Aggarwal [2013], stakeholder theory asserts that corporate sustainability assists in making the relationship that subsists between a firm and stakeholders stronger.

\section{CONCLUSION AND IMPLICATION}

This paper explores the level of attainment of the sustainable development goals by a sample of manufacturing firms in Nigeria and, by so doing, extends extant literature on sustainable development. It is observed that the level of realization of the sustainable development goals by the studied manufacturing firms in Nigeria is low. This finding suggests that manufacturing firms in Nigeria are not doing much with respect to the role they need to play 
in helping Nigerian government to attain the sustainable development goals articulated by the United Nations in 2015. It is further observed that the level of realization of the social strand of the sustainable development goals by the manufacturing firms in Nigeria is high and this implies impressive social performance of manufacturing firms in Nigeria. Also, the environmental performance of the studied firms was found to be abysmal, suggesting that not much is done to ensure sustainable use of the environmental resources by these firms.

The finding has practical implication in that it offers insight that will enable policy makers to insist on tighter environmental measures for manufacturing firms in Nigeria. It also offers an understanding that will enable the management of these firms to have robust basis for formulating environmental policies that will help to improve their firms' level of environmental responsibility. The finding will further help to shade light on the level of efforts made by manufacturing firms in Nigeria towards attaining the sustainable development goals. This knowledge will help the UN to assess the extent that companies have made effort to achieve the rather ambitious and overarching sustainable development goals which they set in 2015 .

The study limitation is centered on the smallness of the sample size which was 10 manufacturing firms. The study is also limited because it focused on manufacturing firms in Nigeria and 2017 annual reports. Accordingly, generalizability will be difficult. So, future studies should increase the number of companies and years and include such other industries as banks and oil and gas when conducting further investigation on the level of realization of SDGs.

\section{References}

Abdul Manab, N., Abdul Aziz, N.A. \& Othman, S.N. (2017). The effect of corporate governance compliance and sustainability risk management (SRM) success factors on firm survival, International Journal of Development and Sustainability, 6(11), 1559-1575.

Aggarwal, P. (2013). Impact of Sustainability Performance of Company on its Financial Performance: A Study of Listed Indian Companies, Global Journal of Management and Business Research Finance, 13(11), 61- 70.

Aras, G. \& Crowther, D. (2008).Governance and sustainability: An investigation into the relationship between corporate governance and corporate sustainability, Management Decision, 46 (3), 433-448.

Boeva, B., Zhivkova, S. \& Stoychev, I. (2017). Corporate Governance and the Sustainable Development. European Journal of Economics and Business Studies, 7(1), 17-24.

Chaklader, B. \& Gulati, P. A. (2015). A Study of Corporate Environmental Disclosure Practices of Companies Doing Business in India. Global Business Review, 16(2), 321-335

Galbreath, J., Singh, I. \& Van der Zahn, J-l, W. M. (2008). The Link between Corporate Governance and Sustainability: Evidence From the Oil \& Gas Industry, Retrieved

fromhttps://espace.curtin.edu.au/bitstream/handle/20.500.11937/41417/20539_downloaded_stream_527.pdf?sequen $\mathrm{ce}=2$

Gatimbu, K.K. \& Wabwire, J. M. (2016). Effect of Corporate Environmental Disclosure on Financial Performance of Firms Listed at Nairobi Securities Exchange, Kenya. International Journal of Sustainability Management and Information Technologies, 2(1), 1-6, Doi: 10.11648/j.ijsmit.20160201.11. 
Groenewald, D. \& Powell, J., (2016) Relationship between sustainable development initiatives and improved company financial performance: A South African perspective. Acta Commercii - Independent Research Journal in the Management Sciences, 16(1), 1-14.

Janggu, T., Darus, F., Zain, M. M., Sawani, Y. (2014). Does good corporate governance lead to better sustainability reporting? an analysis using structural equation modeling, Procedia - Social and Behavioral Sciences , 145, $138-145$.

Jones, P., Hillier, D. \& Comfort, D. (2017.) The Sustainable Development Goals and the Financial Services Industry, Athens Journal of Business \& Economics, 3(1), 37-50.

Jordan, A. (2008). The governance of sustainable development: taking stock and looking forwards. Environment and Planning C: Government and Policy, 26, 17 -33.

Nawaiseh, M. E. (2015). Do Firm Size and Financial Performance Affect Corporate Social Responsibility Disclosure: Employees' and Environmental Dimensions?. American Journal of Applied Sciences, 12 (12), $967-$ 981, DOI: 10.3844/ajassp.2015.967.981.

Okaro, S. C., Ofoegbu, G. N., \& Okafor, G. O. (2018).Corporate Governance and Sustainable Development in Nigeria- Perspectives and Challenges. International Journal of Academic Research in Business and Social Sciences, 8(9), 90-104.

Onwumere, J. U. J. (2009). Business and Economic Research Methods (2 ${ }^{\text {nd }}$ Ed.). Enugu: Vougasen Limited.

Pintea, M. \& Fulop, M. T. (2014). Corporate governance and performance in the context of sustainability development, SEA-practical application of Science, 2(3), 519-526.

Riboldazzi, S. (2016) . Corporate Governance and Sustainability in Italian Large-Scale Retail Companies, European Scientific Journal, 12(16), 1-23. Doi: 10.19044/esj.2016.v12n16p1

Sar, A. K. (2018). Impact of Corporate Governance on Sustainability: A Study of the Indian FMCG Industry. Academy of Strategic Management Journal, 17(1) 1-10.

Stojanović I., Ateljević, J. \& Stević' R. S. (2016). Good Governance as a Tool of Sustainable Development. European Journal of Sustainable Development, 5(4), 558-573. 


\section{APPENDIX}

\section{Sustainable Development Goals Disclosure Index}

\begin{tabular}{|c|l|}
\hline S/N & \multicolumn{1}{|c|}{ Indicators Sustainable Development Goals } \\
\hline $\mathbf{1}$ & Healthy lives \\
\hline $\mathbf{2}$ & Well-being for all \\
\hline $\mathbf{3}$ & Quality education \\
\hline $\mathbf{4}$ & Lifelong learning opportunities \\
\hline $\mathbf{5}$ & Gender equality \\
\hline $\mathbf{6}$ & Empowerment of all women and girls \\
\hline $\mathbf{7}$ & Water and sanitation \\
\hline $\mathbf{8}$ & Affordable, reliable, sustainable and modern energy \\
\hline $\mathbf{9}$ & Productive employment and decent work for all \\
\hline $\mathbf{1 0}$ & Innovation \\
\hline $\mathbf{1 1}$ & Cities and human settlements inclusive, safe, resilient and sustainable \\
\hline $\mathbf{1 2}$ & Sustainable consumption and production patterns \\
\hline $\mathbf{1 3}$ & $\begin{array}{l}\text { Conservation and sustainably use of the oceans, seas and marine } \\
\text { resources }\end{array}$ \\
\hline $\mathbf{1 4}$ & Combat climate change and its impacts \\
\hline $\mathbf{1 5}$ & $\begin{array}{l}\text { Sustainable use of terrestrial ecosystems and reverse land degradation } \\
\text { and halt biodiversity loss }\end{array}$ \\
\hline $\mathbf{1 6}$ & Promote peaceful and inclusive societies \\
\hline $\mathbf{1 7}$ & $\begin{array}{l}\text { Means of implementation and revitalize the global partnership for } \\
\text { sustainable development }\end{array}$ \\
\hline
\end{tabular}

